\title{
KESADARAN BELA NEGARA PADA MAHASISWA
}

\author{
Minto Rahayu' ${ }^{1)}$, Rita Farida ${ }^{2)}$ dan Asep Apriana ${ }^{3)}$ \\ 1,3 Jurusan Teknik Mesin, Politeknik Negeri Jakarta \\ ${ }^{2}$ Jurusan Teknik Sipil, Politeknik Negeri Jakarta \\ E-mail: ${ }^{1}$ minto.rahayu@gmail.com, ${ }^{2}$ r.farida2rocketmail.com, ${ }^{3}$ asep.apriana@mesin.pnj.ic.id
}

\begin{abstract}
Abstrak
Kesadaran bela negara itu hakikatnya ialah kesediaan berbakti pada negara dan kesediaan berkorban membela negara. Tercakup di dalamnya adalah bersikap dan berbuat yang terbaik bagi bangsa dan negara. Wujud bela negara ialah cinta tanah air, kesadaran berbangsa dan bernegara, yakin akan kesaktian Pancasila, rela berkorban untuk bangsa dan negara, serta mempunyai kemampuan awal bela negara. Metode penelitian yang digunakan ialah angket dengan analisis kuantitatif pada nilai mean. Kesadaran bela negara pada mahasiswa diimplemtasikan pada membuang sampah pada tempat yang disediakan, perlindungan dan keamanan bagi masyarakat sudah baik, taat beragama dengan sudah melaksanakan dan menjalankan ibadah dan menjaga kerukunan hidup di antara sesama umat beragama dan kepercayaan terhadap Tuhan yang Maha Esa, sadar telah membina diri saya sendiri agar dapat mandiri kelak, dan bangga kepada perjuangan para pahlawan. Namun ada kesadaran bela negara pada mahasiswa masih kurang yaitu turut menjaga keamanan lingkungan kampus, tidak cukup mewakili kampus dalam kegiatan olah raga dan seni, masih mengedepankan kepentingan pribadi dibadingkan kepentingan bangsa dan negara, cenderung memilih tidak memilih (golput) pada pemilu mendatang, dan kurang berminat menjadi anggota menwa atau tentara.
\end{abstract}

Kata kunci: Bela negara, cinta tanah air, kesadaran berbangsa dan bernegara, yakin akan kesaktian Pancasila, rela berorban, kemampuan awal bela negara

\section{PENDAHULUAN}

Bela negara merupakan hak dan kewajiban bagi seluruh warga negara Indoneisa. Hal ini dinyatakan dalam UUD 1945, pasal 27 ayat 3 tentang Warga Negara dan Penduduk bahwa: Setiap warga negara berhak dan wajib ikut serta dalam upaya pembelaan negara. Pasal 27 ini menitikberatkan pada keikutsertaan dalam menghadapi ancaman dalam segala aspek kehidupan atau sering disebut dengan ancaman nonmiliter. Dalam pasal 30 ayat 1 tentang Pertahanan Keamanan negara, dinyatakan bahwa Tiap-tiap warga negara berhak dan wajib ikut serta dalam usaha pertahanan dan keamanan negara. Pasal ini menitikberatkan pada keikutsertaan bela negara dalam menghadapi ancaman militer, khususnya dalam bidang integrasi bangsa dan negara.
Dalam Undang-undang Republik Indonesia Nomor 3 tahun 2002 tentang Pertahanan Negara, pasal 9 dinyatakan bahwa; Setiap warga negara berhak dan wajib ikut serta dalam upaya bela negara yang diwujudkan dalam penyelenggaraan pertahanan negara. Selanjutnya keikutsertaan warga negara diselenggarakan melalui (1) pendidikan kewarganegaraan, (2) pelatihan dasar kemiliteran secara wajib (3) pengabdian sebagai Tentara Nasional Indonesia (TNI) secara sukarela atau wajib (4) pengabdian sesuai dengan profesi.

\section{Rumusan Masalah}

Berlatar belakang hal di atas, penelitian ini akan menggali kesadaran bela negara pada mahasiswa terhadap unsur bela negara, yaitu cinta tanah air, kesadaran berbangsa dan bernegara, yakin 
akan kesaktian Pancasila, rela berkorban untuk bangsa dan negara, dan memiliki kemampuan awal bela negara. Permasalahan dalam penelitian berjudul Kesadaran Bela Negara pada Mahasiswa ialah:

1. Bagaimana wujud cinta tanah air pada mahasiswa?

2. Bagaimana kesadaran berbangsa dan bernegara pada mahasiswa?

3. Bagaimana tingkat keyakinan kesaktian Pancasila pada mahasiswa?

4. Bagaimana kerelaan berkorban untuk bangsa dan negara pada mahasiswa?

5. Bagaimana kemampuan awal bela negara pada mahasiswa?

\section{Tinjauan Pustaka}

Landasan hukum bela negara yang paling mendasar adalah UUD RI 1945 yang menyatakan bahwa Setiap warga negara berhak dan wajib ikut serta dalam upaya pembelaan negara (pasal 27) dan bahwa Tiap-tiap warga negara berhak dan wajib ikut serta dalam usaha pertahanan dan keamanan negar (pasal 30).

Bela negara meliputi; menyelenggarakan ketertiban umum, menyelenggarakan perlindungan masyarakat, menyelenggarakan keamanan masyarakat, menyelenggarakan perlawanan rakyat semesta. Sedangkan komponen tenaga manusia dalam kekuatan bela negara ialah:

1) Komponen utama adalah Tentara Nasional Indonesia (TNI) yang siap digunakan untuk melaksanakan tugastugas pertahanan,

2) Komponen cadangan adalah sumber daya nasional yang telah disiapkan untuk dikerahkan melalui mobilisasi guna memperbesar dan memperkuat kekuatan dan kemampuan komponen utama,

3) Komponen pendukung adalah sumber daya nasional yang dapat digunakan untuk meningkatkan kekuatan dan kemampuan komponen utama dan komponen cadangan,
4) Sumber daya nasional adalah sumber daya manusia, sumber daya alam, dan sumber daya buatan,

5) Sumber daya alam adalah potensi yang terkandung dalam bumi, air, dan dirgantara yang dalam wujud asalnya dapat didayagunakan untuk kepentingan pertahanan negara,

6) Sumber daya buatan adalah sumber daya alam yang telah ditingkatkan daya gunanya untuk kepentingan pertahanan negara,

7) Sarana dan prasarana nasional adalah hasil budi daya manusia yang dapat digunakan sebagai alat penunjang untuk kepentingan pertahanan negara dalam rangka mendukung kepentingan nasional.

Bela Negara adalah sikap dan tindakan warga negara yang teratur menyeluruh terpadu dan berlanjut yang dilandasi:

1. Cinta Tanah Air; yaitu mencintai ruang wilayah negara baik secara geografis, maupun tata nilai dan tata kehidupan masyarakat yang telah memberikan sumber kehidupan dan penghidupan, sejak manusia lahir sampai pada akhir hayatnya.

2. Kesadaran Berbangsa dan Bernegara; yaitu suatu sikap dan tingkah laku yang sesuai dengan kepribadian bangsa dan selalu mengkaitkan dirinya dengan cita-cita dan tujuan hidup bangsanya, tumbuh rasa kesatuan, persatuan Bangsa Indonesia, memiliki jiwa besar dan patriotisme serta memiliki kesadaran atas tanggungjawab sebagai warga negara.

3. Yakin akan Pancasila sebagai idiologi negara dan pandangan hidup bangsa; yaitu melaksanakan Pancasila sebagai sumber hukum sekaligus sebagai kerangka acuan NKRI karena Pancasila telah dapat mempersatukan Rakyat Indonesia yang terdiri dari beranekaragam agama, suku bangsa, bahasa, asal-usul keturunan. 
4. Rela Berkorban untuk Bangsa dan Negara, artinya seluruh warga negara dituntut rela berkorban dengan mendahulukan kepentingan umum daripada kepentingan pribadi/ golongan.

5. Memiliki Kemampuan Awal Bela Negara; artinya secara psikis, setiap warga negara dituntut untuk memiliki sikap perilaku dispilin, ulet, kerja keras, taat aturan, percaya pada kemampuan sendiri, tahan uji, pantang menyerah, sedangkan secara fisik memiliki kesehatan prima dan tangkas hal tersebut sejalan dengan pepatah kuno yaitu dalam badan sehat terdapat jiwa yang kuat .

\section{HASIL DAN PEMBAHASAN \\ Cinta Tanah Air}

Nilai rata-rata 2,8 kesadaran bela negara pada variabel cinta tanah air, nilai tertinggi yaitu 3,7 ada pada pernyataan nomor 1, yaitu "Saya membuang sampah pada tempat yang disediakan.” sedangkan nilai terendah yaitu 2.1 terdapat pada pernyataan nomor 9, "Saya bersama satpam kampus berpratoli lingkungan kampus.”

\section{Kesadaran Berbangsa dan Bernegara}

Nilai mean pada variabel kesadaran berbangsa dan bernegara cukup baik, 3,3. Artinya mahasiswa telah mempunyai kesadaran akan cita-cita dan tujuan nasional bangsa Indonesia. Nilai tertinggi 3,8 pada pernyataan nomor 20, yaitu "Perlindungan dan keamanan bagi masyarakat sudah baik” sedangkan nilai terrendah 2,3 terdapat pada pernyataan nomor 2, yaitu "Saya mewakili kampus dalam Pekan Olah Raga dan Seni”

\section{Keyakinan akan Kesaktian Pancasila}

Nilai rata-rata pada variabel keyakinan akan kesaktian Pancasila baik, yaitu 3,3. Mahasiswa sudah mempunyai keyakinan bahwa Pancasila sebagai dasar negara dapat dijadikan pedoman dalam kehidupan berbangsa dan bernegara. Nilai tertinggi 3,8 terdapat pada pernyataan nomor 1 dan nomor 3, yaitu "Saya beragama dan menjalankan ibadah sesuai dengan agama saya" dan "Saya senantiasa menjaga kerukunan hidup di antara sesame umat beragama dan kepercayaan terhadap Tuhan yang Maha Esa”. Nilai terendah yaitu 2,8 pada pernyataan nomor 9, yaitu "Kepentingan bangsa dan negara di bawah kepentingan pribadi."

\section{Rela Berkorban untuk Nusa dan Bangsa}

Nilai rata-rata pada variabel rela berkorban untuk nusa dan bangsa ialah 3,9 nilai yang mendekati sempurna (4.0), artinya mahasiswa sudah sangat sadar bahwa dirinya harus rela berkorban untuk nusa dan bangsanya, Indonesia. Nilai tertinggi 3.5 terdapat pada pernyataan nomor 12, yaitu "Saya membina diri saya sendiri agar dapat mandiri kelak." Sedangkan nilai terendah 2,5 terdapat pada pernyataan nomor 8, yaitu "Saya tidak golput pada pemilu mendatang.”

\section{Kemampuan Awal Bela Negara}

Nilai rata-rata pada variabel kemampuan awal bela negara ialah 3,1 dengan nilai tertinggi 3,7 terdapat pada pernyataan nomor 3, yaitu "Saya bangga kepada perjuangan para pahlawan." Sedangkan nilai terendah yaitu 2,3 pada pernyataan nomor 25, yaitu "Saya berminat menjadi anggota menwa atau anggota TNI."

\section{Bela Negara pada Mahasiswa}

Dari hasil dan analisis data bahwa nilai tertinggi dalam kesadaran bela negara mahasiswa pada variabel keyakinan akan kesaktian Pancasila dan nilai terendah pada variabel cinta tanah air. 
Tabel 1: Rangkuman Mean per-Variabel

\begin{tabular}{clc}
\hline No. & \multicolumn{1}{c}{ Variabel } & Mean \\
\hline 1 & Cinta Tanah Air & 278,75 \\
2 & $\begin{array}{l}\text { Kesadaran Berbangsa dan } \\
\text { Bernegara }\end{array}$ & 328,07 \\
3 & $\begin{array}{l}\text { Keyakinan akan Kesaktian } \\
\text { Pancasila }\end{array}$ & 338,5 \\
4 & $\begin{array}{l}\text { Rela Berkorban untuk Nusa dan } \\
\text { Bangsa }\end{array}$ & 293,67 \\
5 & Kemampuan Awal Bela Negara & 306,64 \\
\hline
\end{tabular}

Nilai tertinggi yang juga harus terus dikembangkan dalam setiap variabel ialah; mahasiswa sudah sadar membuang sampah pada tempat yang disediakan, mahasiswa berpendapat bahwa perlindungan dan keamanan bagi masyarakat sudah baik, mahasiswa taat beragama dengan sudah melaksanakan dan menjalankan ibadah sesuai dengan agama saya dan mahasiswa senantiasa menjaga kerukunan hidup di antara sesama umat beragama dan kepercayaan terhadap Tuhan yang Maha Esa, mahasiswa sadar telah membina diri saya sendiri agar dapat mandiri kelak, dan mahasiswa bangga kepada perjuangan para pahlawan.

Sedangkan nilai terendah dan yang perlu diperbaiki dalam setiap variabel ialah; mahasiswa tidak termotivasi dalam turut menjaga keamanan lingkungan kampus, mahasiswa tidak cukup mewakili kampus dalam kegiatan olah raga dan seni, mahasiswa masih mengedepankan kepentingan pribadi dibandingkan kepentingan bangsa dan negara, mahasiswa cenderung memilih tidak memilih (golput) pada pemilu mendatang, dan mahasiswa kurang berminat menjadi anggota menwa atau tentara.

\section{KESIMPULAN DAN SARAN}

\section{Kesimpulan}

1. Kesadaran bela negara pada mahasiswa diwujudkan dalam bentuk cinta tanah air, kesadaran berbangsa dan bernegara, keyakinan akan kesaktian Pancasila, rela berkorban untuk nusa dan bangsa, dan kemampuan awal bela negara.
2. Cinta tanah air diwujudkan pada membuang sampah pada tempat yang disediakan.

3. Kesadaran berbangsa dan bernegara diwujudkan dalam perlindungan dan keamanan bagi masyarakat sudah baik.

4. Keyakinan akan kesaktian Pancasila Kesadaran diwujudkan dalam menjalankan ibadah dan menjaga kerukunan hidup di antara sesama umat beragama dan kepercayaan terhadap Tuhan yang Maha Esa.

5. Rela berkorban untuk nusa dan bangsa diwujudkan dalam kesadaran untuk membina diri saya sendiri agar dapat mandiri kelak.

6. Kemampuan awal bela negara diwujudkan dalam rasa bangga kepada perjuangan para pahlawan.

7. Kesadaran bela negara pada mahasiswa masih kurang dalam hal tidak termotivasi dalam turut menjaga keamanan lingkungan kampus, tidak cukup mewakili kampus dalam kegiatan olah raga dan seni, masih mengedepankan kepentingan pribadi dibadingkan kepentingan bangsa dan negara, cenderung memilih tidak memilih (golput) pada pemilu mendatang, dan kurang berminat menjadi anggota menwa atau tentara.

\section{Saran}

1. Kampus membuat program keikutsertaan mahasiswa dalam ketertiban dan keamanan kampus.

2. Mewajibkan kepada mahasiswa untuk berperan dalam kegiatan kemahasiswaan.

3. Mensosialisasikan bahwa kepentingan bangsa dan negara di atas kepentingan pribadi dan golongan.

4. Memotivasi mahasiswa agar dalam pemilu mendatang mempunyai pilihan yang bertangung jawab.

5. Mendorong mahasiswa latihan fisik untuk siap menjadi patriot dalam bela negara. 


\section{UCAPAN TERIMA KASIH}

Terima kasih penulis sampaikan kepada:

1. Pusat Penenlitian dan Pengabdian kepada Masysrakat, Politeknik Negeri Jakarta, sebagai peyandang dana

2. Rekan-rekan sejawat yang telah membantu dalam memberikan data

\section{DAFTAR PUSTAKA}

Chaidir Basrie (1998) Bela Negara, Implementasi dan Pengembangannya. Jakarta: Universitas Indonesia Pers

Deden Koswara (2014) Implementasi Nilai-nilai Bernegara dalam Kehidupan Bermasyarakat, Berbangsa, dan Bernegara bagi Tegakknya Keutuhan NKRI. Jurnal Islamica Vol 2 Nomor 1 2014

Departemen Pertahanan RI, Direktorat Jenderal Potensi Pertahanan (2006) Tataran Dasar Bela Negara. Jakarta

. . . . (2007). Petunjuk Pelaksanaan tentang Pembinaan Kesadaran Bela Negara. Jakarta

..... 2008. Buku Putih Pertahanan Negara . Jakarta

... . . (2008). Strategi Pertahanan Negara. Jakarta

. . . . (2008). Doktrin Pertahanan Negara. Jakarta

. . . . . (2009). Buku Pedoman Pendidikan Kesadaran Bela Negara bagi Dosen di Perguruan Tinggi. Jakarta

Kuntjaraningrat (1983). Kebudayaan Mentalitas dan Pembangunan. Jakarta: Gramedia

Ketetapan MPR nomor VI 2000 tentang pemisahan TNI dan Polri

Minto Rahayu (2009) Pendidikan Kewarganageraan, Perjuangan Menghidupi Jatidiri Bangsa. Jakarta: Gramedia Widiasarana Indonesia
. . . . . (2009). Persepsi Nasionalisme Mahasiswa dan Perubahan Sosial terhadap Pergerakan Mahasiswa di Era Reformasi (Tesis). Jakarta: Pengkajian Ketahanan Nasional, Universitas Indonesia

. . . . . (2011). Aktualisasi Bela Negara, Penidikan Karakter Berbasis Wawasan Kebangsaan. Program Hibah Buku Teks, Dikti, 2011

Surat Keputusan Menteri Pertahanan Keamanan/Panglima Angkatan Bersenjata nomor Skep/727/VI/1978 (9 Juni).

SK Menhan Nomor Skep 727/VI/1978.

Politeknik Negeri Jakarta. Rencana Induk Pengembangan Pusat Penelitian Politeknik Negeri Jakarta (2011-2015)

Undang-Undang Nomor 29 Tahun 1952 tentang Pertahanan Negara Republik Indonesia

Undang-undang Republik Indonesia Nomor 2 tahun 2002 tentang Kepolisian Negara Republik Indonesia

Undang-undang Republik Indonesia Nomor 3 tahun 2002 tentang Pertahanan Negara

Wan Usman. 2007. Pendidikan dan latihan Bagi Kader Bela Negara Ditinjauan dari Ketahanan Nasional. makalah pada Seminar Forum Komunikasi Pendidikan Badan Pendidikan dan Pelatihan Departemen Pertahanan. Jakarta. 

Kesadaran Bela Negara... 